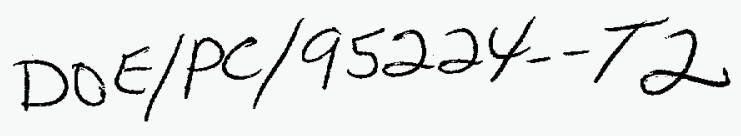

\title{
IN SITU INFRARED STUDY OF CATALYTIC DECOMPOSITION OF NO
}

DE-FG22-95PC95224

Semiannually Technical Progress Report

Steven S. C. Chuang and Cher-Dip Tan

RECEVED

Department of Chemical Engineering

The University of Akron

Akron, Ohio 44325-3906

Anticipated Completion Date: July 31, 1998

Coverment Award ( $\$ \$$ for current year): $\$ 63,661.00$

Program Manager: Dr. Sean I. Plasynski

Principal Investigator(s): Dr. Steven S. C. Chuang

Contracting Officer's Representative (COR): Dr. Eric Bell

Reporting Period: $2 / 1 / 96 \_8 / 1 / 96$

Date of Submission: 9/20/96

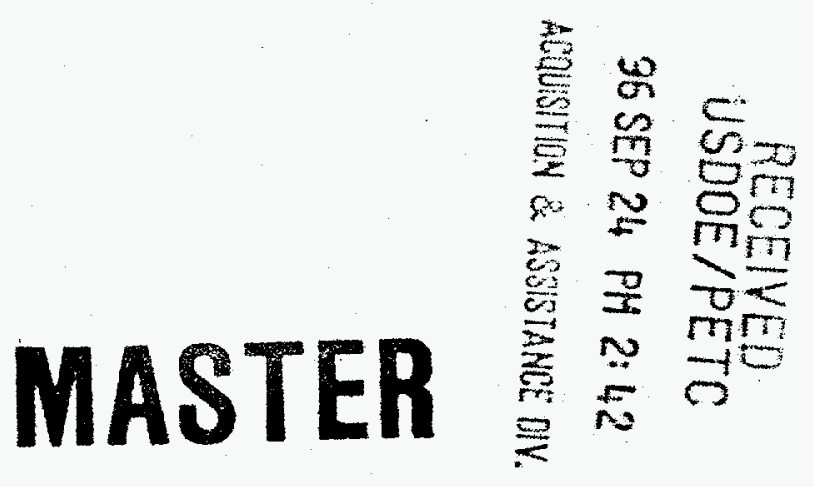




\section{DISCLAMMER}

Portions of this document may be illegible in electronic image products. Images are produced from the best available original document. 


\section{DISCLAIMER}

This report was prepared as an account of work sponsored by an agency of the United States Government. Neither the United States Government nor any agency thereof, nor any of their employees, makes any warranty, express or implied, or assumes any legal liability or responsibility for the accuracy, completeness, or usefulness of any information, apparatus, product, or process disclosed, or represents that its use would not infringe privately owned rights. Reference herein to any specific commercial product, process, or service by trade name, trademark, manufacturer, or otherwise does not necessarily constitute or imply its endorsement, recommendation, or favoring by the United States Government or any agency thereof. The views and opinions of authors expressed herein do not necessarily state or reflect those of the United States Government or any agency thereof. 


\title{
In Situ Infrared Study of Catalytic Decomposition of NO
}

\begin{abstract}
During the second semi-annual period, promotion of oxygen desorption to enhance direct $\mathrm{NO}$ decomposition over $\mathrm{Tb}-\mathrm{Pt} / \mathrm{Al}_{2} \mathrm{O}_{3}$ catalyst has been studied. Promotion of oxygen desorption at low temperatures holds the key to the development of an effective NO decomposition catalyst. Addition of Tb-oxide to $\mathrm{Pt} / \mathrm{Al}_{2} \mathrm{O}_{3}$ allows oxygen from dissociated $\mathrm{NO}$ to desorb at $593 \mathrm{~K}$ which is significantly lower than the reported oxygen desorption temperatures for Pt catalysts. Combined temperature-programmed desorption/reaction with in situ infrared study reveals that desorbed oxygen is produced from decomposition of chelating bidentate nitrato which may be resulted from the reaction of adsorbed oxygen on $\mathrm{Pt}$ and adsorbed $\mathrm{NO}$ on Tb-oxide. The Tb-promoted $\mathrm{Pt}_{\mathrm{Al}} \mathrm{Al}_{2} \mathrm{O}_{3}$ catalyst which possesses oxygen desorption capability at low temperatures shows the activity for decomposition of $\mathrm{NO}$ to $\mathrm{N}_{2}, \mathrm{~N}_{2} \mathrm{O}$, and $\mathrm{O}_{2}$ at $723 \mathrm{~K}$.
\end{abstract}

\section{Introduction}

The direct decomposition of nitric oxide to harmless nitrogen and oxygen is an attractive approach for the control of NO emission because of its chemical simplicity. ${ }^{1}$ The direct NO decomposition, $2 \mathrm{NO} \rightarrow \mathrm{N}_{2}+\mathrm{O}_{2}$, is thermodynamically favorable at temperatures below 2000 K. Development of an effective catalyst for the direct NO decomposition will eliminate the use of reducing reactants, such as $\mathrm{H}_{2}, \mathrm{CO}, \mathrm{NH}_{3}$, and hydrocarbons, significantly simplifying the $\mathrm{NO}$ removal process and dramatically decreasing the cost of NO control for the exhausts of various combustion processes. Extensive catalyst searching and screening studies for the last two decades have led to the discovery of Cu-ZSM-5 catalysts, which exhibit the highest activity for the direct NO decomposition among various catalysts tested. ${ }^{2}$ However, the narrow temperature window of operation for $\mathrm{Cu}-\mathrm{ZSM}-5$, its susceptibility to $\mathrm{SO}_{2}$ poisoning, and rapid deactivation by $\mathrm{H}_{2} \mathrm{O}$ severely limit its potential for practical use. 2,3 Development of a durable catalyst for the direct NO decomposition remains a major challenge in the area of environmental catalysis. ${ }^{4-6}$ 
Knowledge of elementary processes governing the NO decomposition may help guide the development of practical catalysts. Examination of the proposed elementary steps for NO decomposition has revealed that the low NO decomposition activity of a catalyst is due to its inability to desorb oxygen produced from NO dissociation. ${ }^{1}$ Oxygen from dissociated NO is strongly bonded to the catalyst surface, poisoning NO dissociation sites and preventing further NO dissociation. The conventional approach to remove adsorbed oxygen from the catalyst surface includes (i) the utilization of high temperature to desorb adsorbed oxygen and (ii) the employment of gaseous reductant to react with adsorbed oxygen. The former is a high temperature process which requires use of extensive energy; the latter involves a reductant which eliminates the unique advantage of the direct NO decomposition.

A novel approach to improve the activity of a NO decomposition catalyst is to enhance either the desorption of adsorbed oxygen or spillover of adsorbed oxygen from the NO dissociation site. 7,8 Promotion of oxygen desorption should create free sites needed for further NO dissociation. Literature search in the area of oxygen spillover revealed that nonstoichiometric rare earth oxides such as $\mathrm{Tb}$ and $\mathrm{Pr}$ oxides may uptake and release adsorbed oxygen and exhibit self-decomposition activity, releasing oxygen at 773 and $613 \mathrm{~K}$, respectively.9-11 We have, therefore, postulated that the nonstoichiometric rare earth oxides may act as a promoter to either facilitate the spillover of adsorbed oxygen or to promote the desorption of adsorbed oxygen from the NO dissociation site, resulting in enhancing the NO decomposition activity. This letter reports the result of an investigation of the effect of $\mathrm{Tb}$-oxide on the nature (i.e., reactivity and structure) of adsorbates for NO dissociation and for oxygen desorption by a combined in situ infrared spectroscopy and temperature-programmed desorption/reaction technique.

\section{Experimental}

The catalyst used for this study is a 1 wt.\% Tb-Pt/ $\mathrm{Al}_{2} \mathrm{O}_{3}(\mathrm{~Tb}: \mathrm{Pt}=10: 1)$, which was prepared by coimpregnating a solution of $\mathrm{Tb}\left(\mathrm{NO}_{3}\right)_{3} \cdot 5 \mathrm{H}_{2} \mathrm{O}$ (Alfa Products) and $\mathrm{H}_{2} \mathrm{PtCl}_{6} \cdot 6 \mathrm{H}_{2} \mathrm{O}$ 
(Alfa Products) onto a large surface area $\gamma-\mathrm{Al}_{2} \mathrm{O}_{3}$ support (Alfa Products, $100 \mathrm{~m}^{2} / \mathrm{g}$ of surface area, 0.01-0.02 Micron of pore size). The low loading of Pt is used to emulate the loading of precious metal in the automotive catalysts. The ratio of the volume of solution to the weight of alumina support used in the impregnation step was $1 \mathrm{~cm}^{3}$ to $2 \mathrm{~g}$. The catalyst was dried overnight in air at $303 \mathrm{~K}$ after impregnation and then reduced in flowing hydrogen at $673 \mathrm{~K}$ for $8 \mathrm{~h}$. The $\mathrm{Tb}-\mathrm{Pt} / \mathrm{Al}_{2} \mathrm{O}_{3}$ catalyst prepared was characterized by X-ray diffraction (XRD). XRD pattern reveals the presence of $\mathrm{Tb}_{2} \mathrm{O}_{3}$ crystallite and a possible $\mathrm{Tb}_{3} \mathrm{Al}_{2} \mathrm{Al}_{3} \mathrm{O}_{12}$ species on the $\mathrm{Al}_{2} \mathrm{O}_{3}$ surface. The absence of the XRD pattern of Pt crystallite indicates that Pt is highly dispersed on the catalyst with the crystallite size smaller than $30 \AA$.

The details of in situ infrared (IR) reactor cell, experimental apparatus, and procedures have been reported elsewhere. 12 The catalyst powder which has been exposed to air was pressed into three self-supporting disks ( $40 \mathrm{mg}$ each); one of the disks was placed in the IR cell and the other two disks were broken down into flakes and placed at the exit line in the immediate vicinity of the infrared beam path. The additional catalyst disks were used to increase the amount of desorbing species and conversion to obtain a strong signal in the mass spectrometer.

Following the pretreatment of the catalyst in the IR cell with helium flow at $773 \mathrm{~K}$ for $1 \mathrm{hr}$, the catalyst was exposed to $10 \mathrm{~cm}^{3} \mathrm{~min}^{-1}$ of $\mathrm{NO}$ for $10 \mathrm{~min}$ at $303 \mathrm{~K}$. Temperature-programmed desorption/reaction (TPD/R) studies were carried out from 303 to $773 \mathrm{~K}$ at a heating rate of $20 \mathrm{~K}$ min $^{-1}$ with a $40 \mathrm{~cm}^{3} \mathrm{~min}^{-1}$ of He flow. TPD/R is referred to both desorption and reaction of adsorbed NO taking place simultaneously as adsorbates are subject to temperature-programmed heating. Catalyst activity was tested by pulsing either $500 \mu \mathrm{lor} 1 \mathrm{~cm}^{3}$ of NO into $40 \mathrm{~cm}^{3} \mathrm{~min}^{-1} \mathrm{He}$ at 673 and $723 \mathrm{~K}$. Changes in concentration of adsorbates and products during TPD/R and pulse reaction studies were determined simultaneously by infrared spectroscopy and mass spectrometer, respectively.

\section{Results and Discussion}

Figure 1(a) shows the IR spectra of adsorbates during the TPD/R in $40 \mathrm{~cm}^{3} \mathrm{~min}^{-1} \mathrm{He}$ flow following the NO adsorption at $303 \mathrm{~K}$. IR bands below $1400 \mathrm{~cm}^{-1}$ were not observed due to the 
large noise-to-signal ratio and the cutoff of the IR transmission below $1250 \mathrm{~cm}^{-1}$ by $\mathrm{CaF}_{2}$ windows and $\mathrm{Al}_{2} \mathrm{O}_{3}$ support. The initial spectrum, a result of exposure of the catalyst to the NO flow at $303 \mathrm{~K}$, shows the Pt-NO- band at $1646 \mathrm{~cm}^{-1}$ and nitrate bands in the $1630-1400 \mathrm{~cm}^{-1}$ region. The assignment of infrared spectra of adsorbed nitrate species has not been well established. Comparison of the infrared spectra of adsorbed nitrate $\left(\mathrm{NO}_{3}{ }^{-}\right)$with those of nitrato complexes suggests that the $1623 \mathrm{~cm}^{-1}$ band may be assigned to the bridged bidentate, the 1558 $\mathrm{cm}-1$ band and the shoulder band at $1550 \mathrm{~cm}^{-1}$ to the chelating bidentate. ${ }^{13}$

Temperature-programmed desorption/reaction (TPD/R) caused variation in both infrared spectra of adsorbed NO species and eluted rate of gaseous species. In order to clearly discern the change in the concentration of various adsorbates due to TPD/R, spectral differences were taken in Figure 1(b) and compared with the eluted rate of gaseous products in Figure 1(c) to reveal the contribution of the specific adsorbates to the formation of gaseous products. The elution rate of each species was obtained by multiplying its MS intensity with a calibration factor which is determined by injecting a known amount of the species into the MS and measuring the area under the response curve.

Figure 1(a) shows that the intensities of $\mathrm{Pt}_{-} \mathrm{NO}^{-}$at $1646 \mathrm{~cm}^{-1}$, and bidentate nitrates in the $1545-1500 \mathrm{~cm}^{-1}$ region began to decrease at temperatures above $333 \mathrm{~K}$. The decrease in the intensity of these bands is highlighted in Figure 1(b) by the negative difference spectrum for 423$323 \mathrm{~K}$ where $\mathrm{NO}, \mathrm{N}_{2}$ and $\mathrm{N}_{2} \mathrm{O}$ evolved, giving the peak temperature at $373 \mathrm{~K}$ in Figure $1(\mathrm{c})$. The amount of $\mathrm{NO}, \mathrm{N}_{2}$, and $\mathrm{N}_{2} \mathrm{O}$ desorbed under the $373 \mathrm{~K}$ peak corresponds to $30.6,20.7$, and 1.0 $\mu \mathrm{mol}$, respectively. Formation of $\mathrm{N}_{2}$ and $\mathrm{N}_{2} \mathrm{O}$ suggests the occurrence of

$$
\begin{aligned}
& 2 \mathrm{NO}_{\mathrm{ad}} \rightarrow \mathrm{N}_{2}+2 \mathrm{O}_{\mathrm{ad}} \\
& 2 \mathrm{NO}_{\mathrm{ad}} \rightarrow \mathrm{N}_{2} \mathrm{O}+\mathrm{O}_{\mathrm{ad}}
\end{aligned}
$$

Stoichiometry of reactions 1 and 2 suggests that the formation of these $\mathrm{N}_{2}$ and $\mathrm{N}_{2} \mathrm{O}$ at 373 $\mathrm{K}$ peak should leave $42.4 \mu \mathrm{mol}$ of adsorbed oxygen on the catalyst surface. Adsorbed oxygen on the surface of metal and metal oxide can not be observed from this study because its vibrational frequency in $200-450 \mathrm{~cm}^{-1}$ region ${ }^{14}$ is below the IR transmission range of $\mathrm{CaF}_{2}$ and $\mathrm{Al}_{2} \mathrm{O}_{3}$ 
support used in this study. Adsorbed oxygen did not desorb as gaseous oxygen molecule until temperature reaching $593 \mathrm{~K}$. In the temperature range between 423 and $593 \mathrm{~K}$, the main TPD-IR feature is the constant NO elution rate (Fig. 1c) with a substantial decrease in the bidentate bands at 1623 and $1523 \mathrm{~cm}^{-1}$. A marked decrease in IR intensity of these bidentate bands has also been observed with $\mathrm{NO}$ elution in the same temperature range during TPD/R of adsorbed $\mathrm{NO}$ on $\mathrm{Al}_{2} \mathrm{O}_{3}$. The similarity in the negative difference spectra for these two catalysts suggests the bidentate nitrates at 1623 and $1523 \mathrm{~cm}^{-1}$ is a result of direct adsorption of $\mathrm{NO}$ on the $\mathrm{Al}_{2} \mathrm{O}_{3}$ surface.

At temperatures above $593 \mathrm{~K}$, adsorbed oxygen began to desorb and exhibited the peak at $683 \mathrm{~K}$ while difference $\mathrm{R}$ spectra showed a significant decrease in the intensity of the $1558 \mathrm{~cm}^{-1}$ band. The amount of desorbed oxygen $(4.7 \mu \mathrm{mol})$ is less than that of oxygen produced during the formation of $\mathrm{N}_{2}$ and $\mathrm{N}_{2} \mathrm{O}$ at $373 \mathrm{~K}$.

Since a practical catalyst for NO decomposition must work in an oxidizing environment, the catalyst was further treated with air at $773 \mathrm{~K}$ for $1 \mathrm{hr}$ and then cooled down to $303 \mathrm{~K}$ in helium for $\mathrm{NO}$ adsorption and TPD/R studies to determine the activity of the oxidized $\mathrm{Tb}-\mathrm{P} t / \mathrm{Al}_{2} \mathrm{O}_{3}$ for the NO decomposition. Figure 2(a) shows the IR spectra during the NO TPD/R on the oxidized Tb$\mathrm{Pt} / \mathrm{Al}_{2} \mathrm{O}_{3}$. Comparison of results in Figures 1 and 2 reveals the effect of air-treatment at $773 \mathrm{~K}$ on the reactivity of adsorbates and the catalyst surface state. The air-treatment led to the following changes in IR spectra and TPD/R product profiles:

- Air-treatment decreased the intensity of Pt-NO- band at $1646 \mathrm{~cm}^{-1}$ by $50 \%$.

- Air-treatment decreased the amount of $\mathrm{N}_{2}$ formation and completely suppressed $\mathrm{N}_{2} \mathrm{O}$ formation.

- Air-treatment increased the amount of $\mathrm{O}_{2}$ and $\mathrm{NO}$ desorbed at $683 \mathrm{~K}$.

These changes brought about by the air-treatment suggest that (i) formation of $\mathrm{N}_{2} \mathrm{O}$ requires a large fraction of reduced Pt surface; and (ii) $\mathrm{Pt}_{-} \mathrm{NO}^{-}$may be the precursor for the NO dissociation. One common feature between the reduced and air-treated catalysts is that oxygen desorption at $683 \mathrm{~K}$ is closely related to a significant decrease in IR intensity of chelating bidentate at $1558 \mathrm{~cm}^{-1}$. A subtle difference in the formation of chelating bidentate on these two catalysts was noted. The majority 
of chelating bidentate was formed during $\mathrm{NO}$ adsorption on $\mathrm{Tb}-\mathrm{Pt} / \mathrm{Al}_{2} \mathrm{O}_{3}$ at room temperature while some of chelating bidentate was generated on air-treated $\mathrm{Tb}-\mathrm{Pt} / \mathrm{Al}_{2} \mathrm{O}_{3}$ at $333-473 \mathrm{~K}$.

The above observations led to postulation of the following pathway for the decomposition of $\mathrm{NO}$ to $\mathrm{N}_{2}, \mathrm{~N}_{2} \mathrm{O}$ and $\mathrm{O}_{2}$ on the $\mathrm{Tb}-\mathrm{Pt} / \mathrm{Al}_{2} \mathrm{O}_{3}$ :

$$
\begin{array}{ll}
\text { Step 1. } & \mathrm{NO}+\mathrm{Pt} \rightarrow \mathrm{Pt}-\mathrm{NO}^{-} \\
\text {Step 2. } & \mathrm{NO}+\mathrm{TbO}_{\mathrm{x}} \rightarrow \mathrm{TbO}_{\mathrm{x}}-\mathrm{NO} \\
\text { Step 3. } & \mathrm{Pt}-\mathrm{NO}^{-}+\mathrm{Pt} \rightarrow \mathrm{Pt}-\mathrm{N}+\mathrm{Pt}-\mathrm{O} \\
\text { Step 4. } & 2 \mathrm{Pt}-\mathrm{N} \rightarrow \mathrm{N}_{2}+2 \mathrm{Pt} \\
\text { Step 5. } & \mathrm{Pt}-\mathrm{N}+\mathrm{Pt}-\mathrm{NO} \rightarrow \mathrm{N}_{2} \mathrm{O}+2 \mathrm{Pt} \\
\text { Step 6. } & 2 \mathrm{Pt}-\mathrm{O}+\mathrm{TbO}_{\mathrm{x}}-\mathrm{NO} \rightarrow 2 \mathrm{Pt}+\mathrm{TbO}_{\mathrm{x}}-\mathrm{NO}_{3} \text { (chelating bidentate) } \\
\text { Step 7. } & \mathrm{TbO}_{\mathrm{x}}-\mathrm{NO}_{3} \rightarrow \mathrm{TbO}_{\mathrm{x}}+\mathrm{NO}+\mathrm{O}_{2}
\end{array}
$$

It should be noted that the whole Pt-NO- entity should be considered neutral. The proposed pathway for the formation of gaseous oxygen molecules from TPD/R involves (i) the dissociation of adsorbed NO on the Pt surface, step 1, at temperatures below $473 \mathrm{~K}$, (ii) the reaction of adsorbed oxygen with adsorbed NO on the Tb oxide surface to form a chelating bidentate species, step 6 , and (iii) the decomposition of the chelating bidentate to produce $\mathrm{NO}$ and $\mathrm{O}_{2}$, step 7 , at temperatures above $593 \mathrm{~K}$.

To compare the oxygen desorption profile of $\mathrm{Pt}_{/} \mathrm{Al}_{2} \mathrm{O}_{3}$ and $\mathrm{Tb}-\mathrm{Pt} / \mathrm{Al}_{2} \mathrm{O}_{3}$, TPD/R of adsorbed $\mathrm{NO}$ was also carried out on $\mathrm{Pt} / \mathrm{Al}_{2} \mathrm{O}_{3} . \mathrm{O}_{2}$ was not found in the temperature range of $303-873 \mathrm{~K}$ during TPD/R of adsorbed $\mathrm{NO}$ on $\mathrm{Pt}_{/} \mathrm{Al}_{2} \mathrm{O}_{3}$. Due to the operating temperature limit of the IR cell, TPD/R was not able to conduct at temperatures above $873 \mathrm{~K}$. Oxygen from dissociated NO has been found to desorb at $1000 \mathrm{~K}$ for Pt(111) surface which does not exhibit NO decomposition activity in the 673-973 K. ${ }^{15}$ Lowering the oxygen desorption temperature on the $\mathrm{Tb}-\mathrm{Pt} / \mathrm{Al}_{2} \mathrm{O}_{3}$ should facilitate desorption of adsorbed oxygen and regenerate sites needed for $\mathrm{NO}$ dissociation to complete the catalytic site for NO decomposition.

Since the oxygen desorption peak temperature was observed near $673 \mathrm{~K}$ on Tb-Pt/ $\mathrm{Al}_{2} \mathrm{O}_{3}$, the activity of the catalyst was first tested at $673 \mathrm{~K}$ by pulsing $500 \mu \mathrm{l}$ of NO into helium carrier gas 
over the catalyst. Pulse reaction studies allow accurate determination of mass balance which provides information on the moles of gaseous reactant entering the reactor and those of gaseous products leaving the reactor. Figure 3 shows the response of the IR reactor effluent composition. The number near each peak of the response indicates the amount $(\mu \mathrm{mol})$ of the species determined by the area under each peak multiplied by its calibration factor. The $500 \mu \mathrm{l}(20.1 \mu \mathrm{mol}) \mathrm{NO}$ pulses produced $\mathrm{N}_{2}$ and $\mathrm{N}_{2} \mathrm{O}$ at $673 \mathrm{~K}$. Lack of oxygen formation indicates that the catalytic cycle for the decomposition of $\mathrm{NO}$ to $\mathrm{N}_{2}$ and $\mathrm{O}_{2}$ was not complete; formation of gaseous $\mathrm{N}_{2}$ and $\mathrm{N}_{2} \mathrm{O}$ leaves oxygen from dissociated NO on the catalyst. The $500 \mu 1 \mathrm{NO}$ pulses were continued at $723 \mathrm{~K}$ in an attempt to facilitate oxygen desorption. The initial four $500 \mu \mathrm{l}$ and one $1 \mathrm{ml} \mathrm{NO}$ pulses produced only $\mathrm{N}_{2}$ as a product; and infrared spectra remain unchanged as the NO pulsed through the catalyst disk. The absence of variation of IR spectra indicates that (i) the residence time and concentration of adsorbates resulting from NO pulses are too low for adsorbates to be detected by infrared spectroscopy or (ii) the adsorbates produced from the NO pulse are not in the IR-active form. Further NO pulses produced $\mathrm{N}_{2}, \mathrm{~N}_{2} \mathrm{O}$ and $\mathrm{O}_{2}$. Although the formation of $\mathrm{O}_{2}$ indicates completion of the catalytic cycle for $\mathrm{NO}$ decomposition to $\mathrm{N}_{2}$ and $\mathrm{O}_{2}$, the amount of $\mathrm{O}_{2}$ produced remains significantly less that of $\mathrm{N}_{2}$ and $\mathrm{N}_{2} \mathrm{O}$, indicating the accumulation of oxygen on the catalyst. In the $10 \mathrm{NO}$ pulses at $723 \mathrm{~K}, 0.26 \mu \mathrm{mol}$ of gaseous oxygen was desorbed. The accumulated oxygen was further released after a series of NO/air pulses.

\section{Conclusions}

Combined TPD/R with in situ IR study reveals that both $\mathrm{Tb}-\mathrm{Pt} / \mathrm{Al}_{2} \mathrm{O}_{3}$ and air-treated Tb$\mathrm{Pt} / \mathrm{Al}_{2} \mathrm{O}_{3}$ catalysts exhibit $\mathrm{O}_{2}$ desorption profile centered at $693 \mathrm{~K}$. The $\mathrm{O}_{2}$ desorption is resulted from decomposition of chelating bidentate nitrato which is produced from the direct exposure of the catalysts to gaseous NO. The $\mathrm{Tb}-\mathrm{Pt} / \mathrm{Al}_{2} \mathrm{O}_{3}$ catalysts which exhibit low-temperature $\mathrm{O}_{2}$ desorption show the activity for NO decomposition at temperatures above $723 \mathrm{~K}$ under the pulse reaction condition. Further study is underway to determine the effect of air, $\mathrm{H}_{2} \mathrm{O}$, and $\mathrm{SO}_{2}$ on the NO decomposition under steady-state flow condition. 


\section{Acknowledgment}

The authors gratefully acknowledge financial support for this research from the U.S. Department of Energy grant number DE-FG22-95PC95224. 


\section{References}

1. Hightower, J. W.; Van Leirsburg, D. A., The Catalytic Chemistry of Nitrogen Oxides; R. L. Klimisch and J. G. Larson, Eds.; Plenum Press, New York, 1975; p. 63.

2. Iwamoto, M.; Studies in Surface Science and Catalysis; Misono, M., Moro-oka, Y., and Kimura, S. Eds.; Vol. 54, Elsevier, Amsterdam, 1990, p. 121.

3. Li, Y.; Hall, W. K. J. Phys. Chem. 1990, 94, 6140.

4. Li, Y.; Armor, J. N. Appl. Catal. 1991, 76, L1.

5. Kung, M. C. Catal. Lett. 1993, 18, 111.

6. Aylor, A. W.; Larsen, S. C.; Reimer, J. A.; Bell, A. T. J. Catal. 1995, 157, 592.

7. Tan, C.-D.; Krishnamurthy, R.; and Chuang, S. S. C. Abstract of 33rd Annual Spring Symposium of the Pittsburgh-Cleveland Catalysis Society, Pittsburgh, PA, May 10-11, 1995.

8. Chuang, S. S. C.; Krishnamurthy, R.; Tan, C.-D.; Brundage, M. Abstract of 7th JapanChina-USA Symposium on Catalysis, Tokyo, Japan, July 26-28, 1995; p. O-29.

9. Kyomasu, A.; Okuhara, T.; Misons, M. Nippon Kagaku Kaishi 1991, 5, 651.

10. Takasu, Y.; Yoko-o, T.; Matsui, M.; Matsuda, Y.; Toyoshima, I. J. Catal. 1982, 77, 485.

11. Takasu, Y.; Matsui, M.; Tamura, H.; Kawamura, S.; Matsuda, Y.; Toyoshima, I. J. Catal. 1981, 69, 51 .

12. Chuang, S. S. C.; Brundage, M. A.; Balakos, M. W.; Srinivas, G. Appl. Spec. 1995, 49(8), 1151.

13. Nakamoto, K. Infrared and Raman Spectra of Inorganic and Coordination Compounds, 4th ed.; John Wiley \& Sons: New York, 1986; Part III.

14. Fisher, G. B.; DiMaggio, C. L.; Beck, D. D. In New Frontiers in Catalysis: Proceedings of the 10th International Congress on Catalysis, 1992; Guczi, L., Solymosi, F., Tetenyi, P., Eds.; Akademiai Kiado: Budapest, Hungary, 1993; Part A, p. 383.

15. Gland, J. L.; Sexton, B. A.; Fisher, G. B., Surf. Sci. 1980, 95, 587. 


\section{Figure Captions}

Figure 1. (a) Infrared spectra during $\mathrm{NO} \mathrm{TPD} / \mathrm{R}$ on $1 \mathrm{wt} . \% \mathrm{~Tb}-\mathrm{Pt} / \mathrm{Al}_{2} \mathrm{O}_{3}$ at a heating rate of $20 \mathrm{~K}$ $\min ^{-1}$ from 303 to $773 \mathrm{~K}$. (b) Spectral differences; the $423-333 \mathrm{~K}$ spectrum is a result of the subtraction of IR absorbance at $333 \mathrm{~K}$ from that at $423 \mathrm{~K}$. (c) Rate of elution for gaseous species from the IR cell and variation of IR intensities with temperature.

Figure 2. (a) Infrared spectra during NO TPD/R on oxidized $1 \mathrm{wt} . \% \mathrm{~Tb}-\mathrm{Pt} / \mathrm{Al}_{2} \mathrm{O}_{3}$ at a heating rate of $20 \mathrm{~K} \mathrm{~min}^{-1}$ from 303 to $773 \mathrm{~K}$. (b) Spectral differences. (c) Rate of elution for gaseous species from the IR cell and variation of IR intensities with temperature.

Figure 3. MS response of the IR reactor effluent composition during the pulse NO reaction on 1 wt. \% Tb-Pt/Al ${ }_{2} \mathrm{O}_{3}$ at 673 and $723 \mathrm{~K}$. The number near each peak of the response indicates the amount $(\mu \mathrm{mol})$ of the species. 

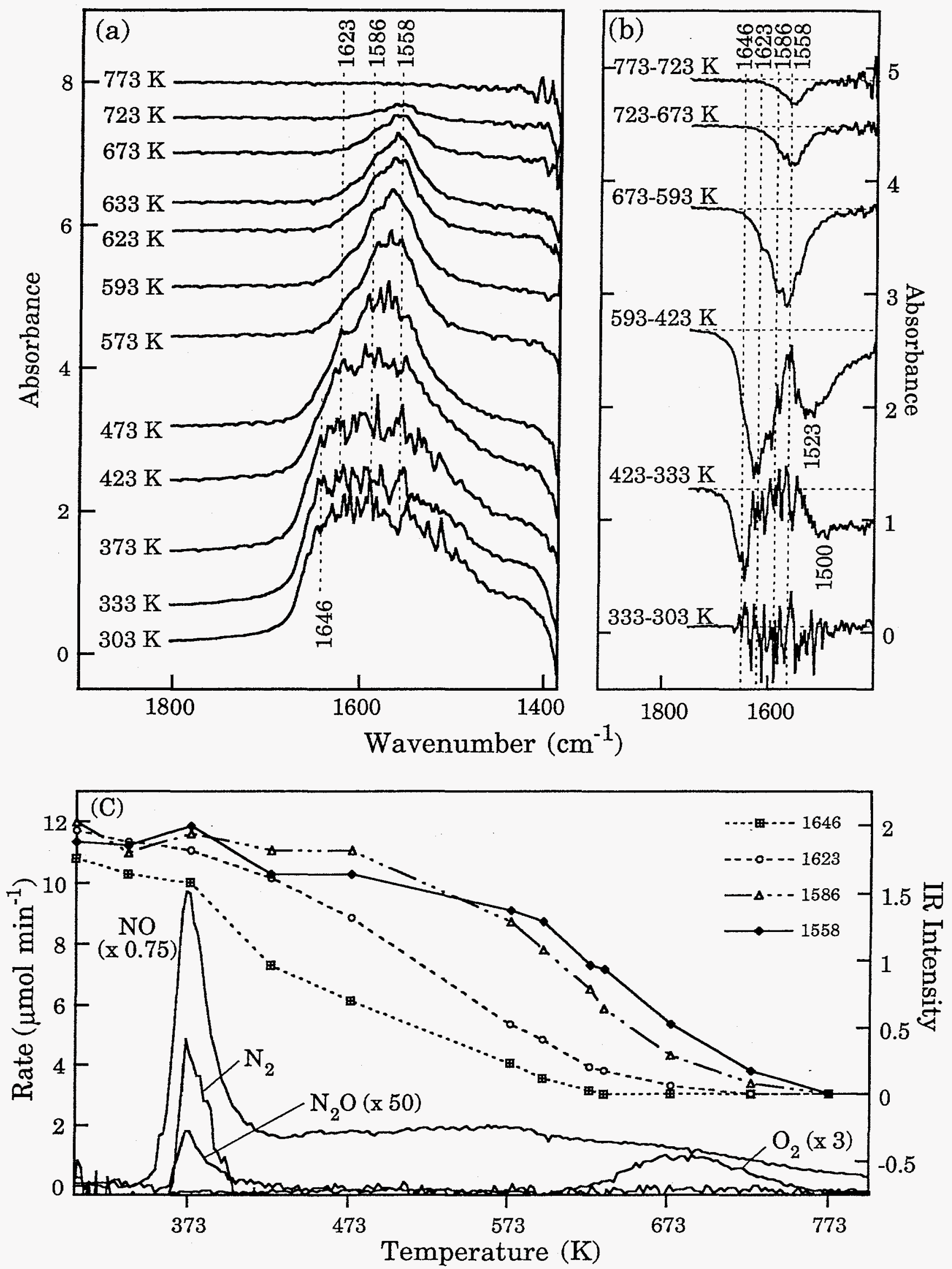

Fig 1 

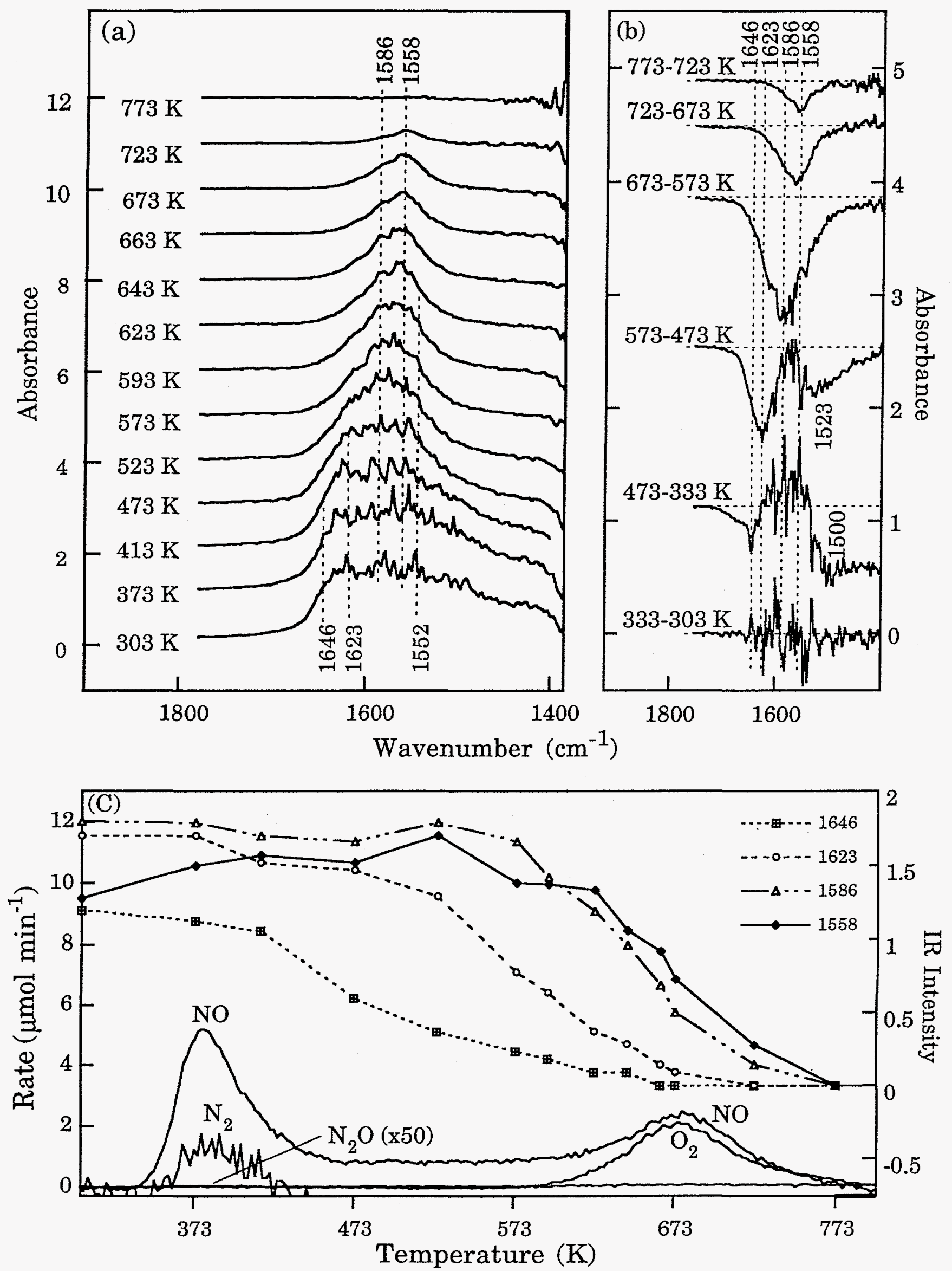


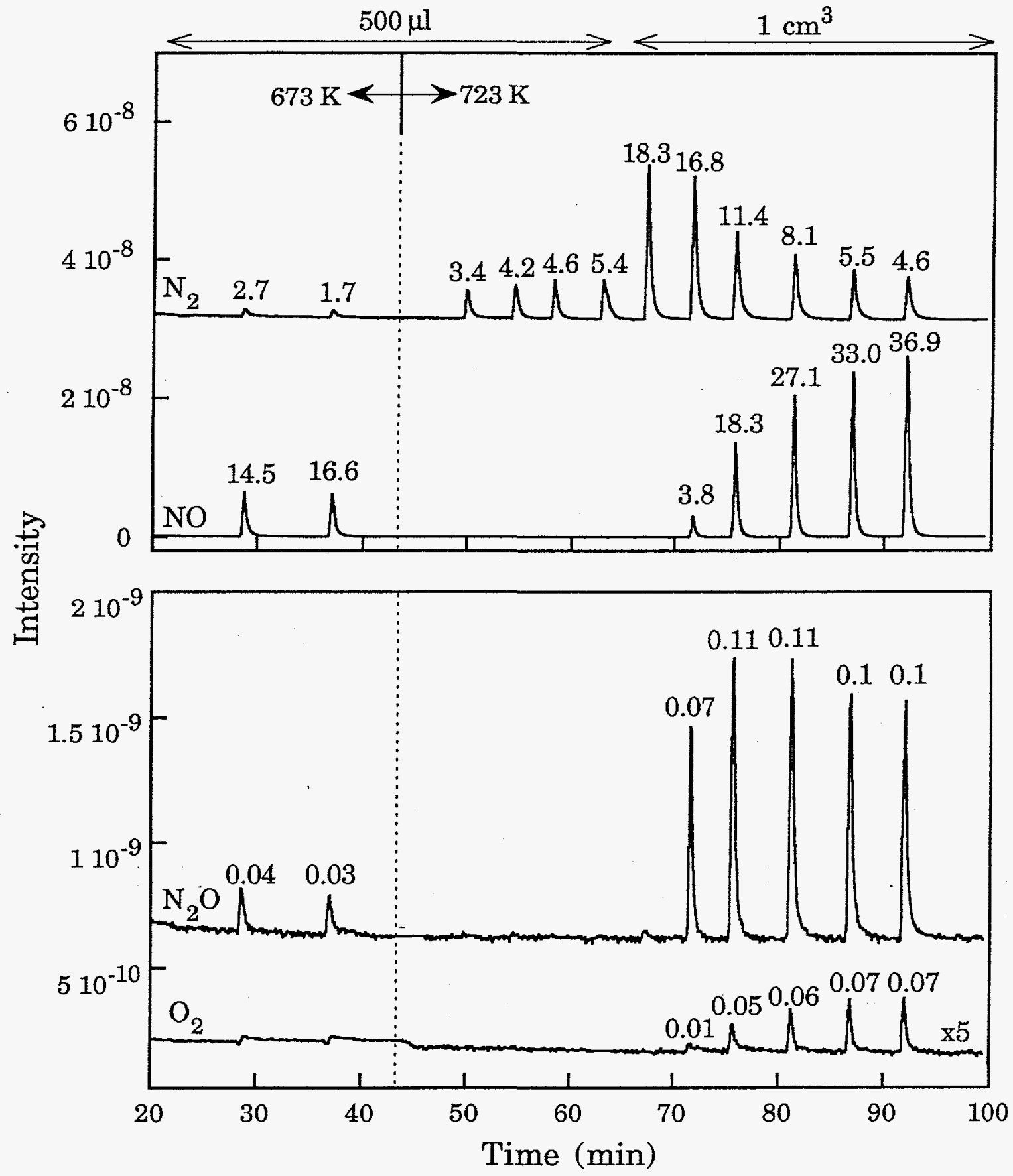

Fig 3

Chuang and Tan 